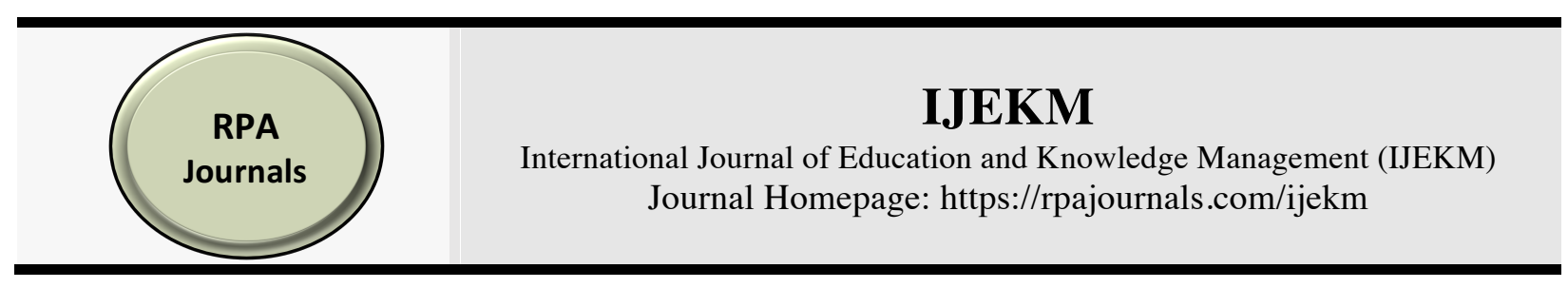

\title{
The Effect of Interactive Multimedia to Improve the Cognitive Learning Outcome in Senior High School's Student
}

\author{
Roemintoyo', \\ Agus Efendi ${ }^{2}$, \\ Mochamad Kamil Budiarto, \\ Hilmawan Wibawanto ${ }^{4}$ \\ Sebelas Maret University, Indonesia ${ }^{12,34}$
}

\begin{abstract}
Technology use has been applied to many fields, including education as indicated with the development of handphone-based interactive multimedia. This research aims to examine the effectiveness of interactive multimedia in excretion system. This study was a quasi-experimental research with pre-post control group design. This research was conducted on the 2nd graders of Senior High School in East Ogan Komering Ulu (OKU) Regency. The result of t-test showed significance value of 0.038 ( $\mathrm{sig}<0.05$ ). The difference of pretest and post-test mean values increases (gain) by 2.3 points in experiment class; it is higher than that in control class (1.6 points). Considering the difference of mean value, it can be concluded that experiment class is superior to control class. It indicates that the treatment using interactive multimedia affect significantly the improvement of students' cognitive learning achievement. Thus, it can be concluded that interactive multimedia improves the students' cognitive learning achievement effectively in experiment class.
\end{abstract}

Keywords: Interactive multimedia, Excretion system, student's outcome

*Corresponding author: Mochamad Kamil Budiarto; Email: kamiltp@student.uns.ac.id DOI: https://doi.org/10.37227/IJEKM-2021-01-34

\section{Introduction}

A very rapid development of science and technology results in the change in nearly all human activities. Technology is a messenger that can be used for learning purpose (Singh, 2016; Schramm, 1977). So, media is the expansion of teacher. In education sector, interactive multimedia has been developed currently to facilitate the human's learning activity. Multimedia learning is a common name used to explain cognitive theory of multimedia learning, the theory involving several learning principles using multimedia as teaching media (Mayer, R.E. \& Moreno, R.,1998). Interactive multimedia is one of learning media types with an ability of displaying material in audiovisual form and enabling the interaction to occur between students and media. The use of interactive multimedia as a learning media variation results in the effective communication process between teachers and students in learning. Effective communication is related to its communicator and communicant's ability. Ability is our capability, competency, and power to make our own endeavor (Edwards \& Wilson, 2017; Moeliono : 2003). 
Communication is effective, according to Santoso (1982), when communicator and communicant have shared understanding or definition of a message or in other words the communication is in tune". The less effective communication can result in miscommunication between teachers and students, so that the message received by students is different from the message delivered by teacher. Miscommunication in learning activity can result in fatality as it can lead to material misconception. The effect generated can be identified directly through the output of students' exam value, but some others can be brought into students' daily activity thereby affecting the students' decision making behavior (Edwards \& Wilson, 2017; Guzman \& Lewis, 2020).

The result of document analysis conducted in Senior High Schools of East Ogan Komering Ulu (OKU) showed that students' understanding on biology learning material is still low (poor) as indicated with the daily exam score of $6.5 \%$. The result of analysis on national exam for biology subject, particularly excretion system material during 2015-2018 obtains mean score of $6.1 \%$. Considering the class observation, a factor putatively resulting in the students' poor understanding is less effective learning process. Learning activity is dominated with lecturing and discussion. The media used is only PowerPoint with lowquality slide display as it is dominated with text and low-resolution image. It is in contradiction with the requirements of good PowerPoint preparation for learning media: consistent format, varying type of letter use, appropriate color combination, well-established transition effect, appropriate animation use and placement, interconnected slide display, and concise and clear sentence use (Serin, 2018; Sugiyati, 2016).

An attempt to be taken to make the learning activity running effectively is to use interactive multimedia. One of multimedia' advantages in learning, according to Munir (2012) to attract the students in order to generate their learning interest, motivation, activity, and creativity. Interactive multimedia is designed to display material in the form of text, image, video, audio, and to support students' discussion activity through internet network. Interactive multimedia is operated using smartphone as it has high flexibility and portability, thereby improving the interaction between students and material (Maharani et al., 2018). Smartphone use is supported with the data resulting from the observation on students' learning facilities, indicating that $100 \%$ of students have had smartphone and always bring it with them wherever they go, including to school.

Currently cellular phone is a most useful technology ware that can be utilized as learning media (Behera, 2013). Smartphone is a mobile computing set with very rapid hardware development. Android keeps developing until today both in its system and application (Dadang, 2013). Smartphone processor with single core number in 2011 develops into octa core in 2018, the storage memory increases from $300 \mathrm{MB}$ to $64 \mathrm{~GB}$, and connectivity is getting faster with the use of $4 \mathrm{G} \mathrm{LTE}$ technology. These advantages give the author the opportunity of running an information-rich multimedia with a variety of multimedia elements. Departing from the background elaborated, the author is interested in studying "The Effectiveness of interactive multimedia in excretion system material to improve the cognitive learning outcome of Senior High School students in OKU Timur Regency".

\section{Literature Review}

Conceptually interactive multimedia is a learning program or application that can be run through a computer device which is composed of several components such as video, animation, audio, graphics, and text that are integrated with each other (Abdillah et al., 
2018). Some of the relationships inherent in interactive multimedia for the learning process consist of, 1) having more than one convergent media, for example combining audio and visual elements, 2) being interactive, in the sense of having the ability to accommodate user responses, namely providing completeness and completeness of content or information in such a way that users can use multimedia programs without guidance from others (Neo \& Neo, 2010; Guan et al., 2018).

If interactive multimedia that was developed and utilized hds fulfilled several characteristics as mentioned above, then the function of interactive multimedia as a learning media will be optimal. As mentioned by Suyantiningsih et al. (2016) \& Lau et al. (2014) that interactive multimedia has several functions, including, 1) being able to strengthen user responses as quickly and as often as possible, 2) being able to provide opportunities for students to control the pace of their own learning styles, 3) noting that students follow a clear and controlled sequence, and 4) involve activities of sight, hearing, and touch.

Interactive multimedia for the learning process is now widely used at all levels of education starting from elementary to tertiary education. The distinguishing feature of each development and use of multimedia learning is that it is adjusted to the level of student cognitive development, student learning style and rhythm (Saputri et al., 2018). Some of the novelties of the use of multimedia in the learning process in the last few years are to include motivational factors through emotional design in multimedia learning (Leutner, 2014; Park et al., 2014). As the results of research conducted by Kumar et al. (2019) regarding an emotion which is an important aspect of learning, he explores methods to investigate how emotions can be manipulated in a positive way so that they can influence online learning, which in turn shows that emotional design is a better predictor of cognitive outcomes. , whereas IE is a better predictor of emotional outcomes such as motivation and satisfaction for multimedia-based learning. It was also found that positive and negative designs have the same effect on student learning outcomes, whereas EI affects the perception of satisfaction in each of the learning designs.

Other studies have also stated that interactive multimedia has an effect on student achievement, as was done by Wang et al. (2019) found differences in learning achievement results between the control group and the experimental group, the control group had significantly lower scores on the visual task than the experimental group, but no significant difference in scores was found on verbal tasks between the three groups of research subjects. The use of technology, especially interactive multimedia in the learning process, can also have an effect on strengthening student character, as in research conducted by Sholihah et al. (2020) which has successfully developed an interactive multimedia product called IMONEC, which integrates three important components, namely the principle of interactive multimedia learning, the principle of the Bandura observational learning model, and national historical events into interactive multimedia products that are suitable for use as learning media, with the results of expert assessments media obtained a score of $95.83 \%$, material experts obtained a score of $97.57 \%$, and learning practitioners $85.57 \%$ of the total $100 \%$, the results of this media also show that interactive multimedia developed can strengthen student character during education and citizenship learning, in harmony With this research, Komalasari \& Rahmat (2019) revealed that the use of interactive multimedia in the learning process of education and citizenship can also be integrated with life values which have an impact on strengthening student character.

\section{Research Methodology}


This study is a quasi-experiment. Experimental research method can be defined as the one used to find out the effect of certain treatment on others in uncontrolled condition (Sugiyono : 2013). The designed used was pre post control group design. The sample was taken using cluster random sampling technique, consisting of 64 students on 11th Science graders of Semendawai Senior High School Suku III East OKU divided into control and experiment classes. The students in experiment class are given treatment using interactive multimedia of excretion. The students in control class use the media used in conventional learning: power point and textbook. Learning cycle is repeated in 3 meetings. In the end of meeting, the two classes undertook the test using cognitive test instrument consisting of 25 multiple choice items that have been tested for its reliability and validity. The result of cognitive value is tested using independent sample t-test preceded by homogeneity and normality prerequisite test to find its effectiveness.

\section{Results and Analysis}

This research aims to test the hypothesis stating that interactive multimedia can improve the students' cognitive learning outcome in excretion system material. The data taken includes students' cognitive pre-test and post test scores. Data was taken using a valid and reliable cognitive test instrument. The result of cognitive pretest and posttest is presented in Table 1.

\begin{tabular}{lllll}
\multicolumn{4}{l}{ Table 1. Result of cognitive test for experiment an control test } \\
\hline Class & $\begin{array}{l}\text { Mean } \\
\text { Pre-test }\end{array}$ & $\begin{array}{l}\text { Mean } \\
\text { Post- } \\
\text { test }\end{array}$ & $\begin{array}{l}\text { Difference } \\
\text { of Post-Pre }\end{array}$ & $\begin{array}{l}\text { Std } \\
\text { Deviasi }\end{array}$ \\
\hline Experiment & 13.5 & 15.8 & 2.3 & 1.33 \\
\hline Control & 12.9 & 14.5 & 1.6 & 1.52 \\
\hline
\end{tabular}

From Table 1, it can be seen that pre-test value of experiment class is 13.5. Having been treated using interactive multimedia, the mean posttest value of excretion system increases to 15.8 in experiment class. There is an increase by 2.3 points in cognitive learning outcome for the students in experiment class. As the comparator of the cognitive learning outcome for experiment class, the media usually used by teacher during teaching is used in the learning process in control class. The media used is power point and textbook. The result of pretest control class obtains mean score of 12.9 point, while the result of posttest shows mean score of 14.5. Just like in experiment class, there is also an increase by 1.6 point in control class. The increase of pretest and posttest results in control and experiment classes is displayed in Figure 1. 


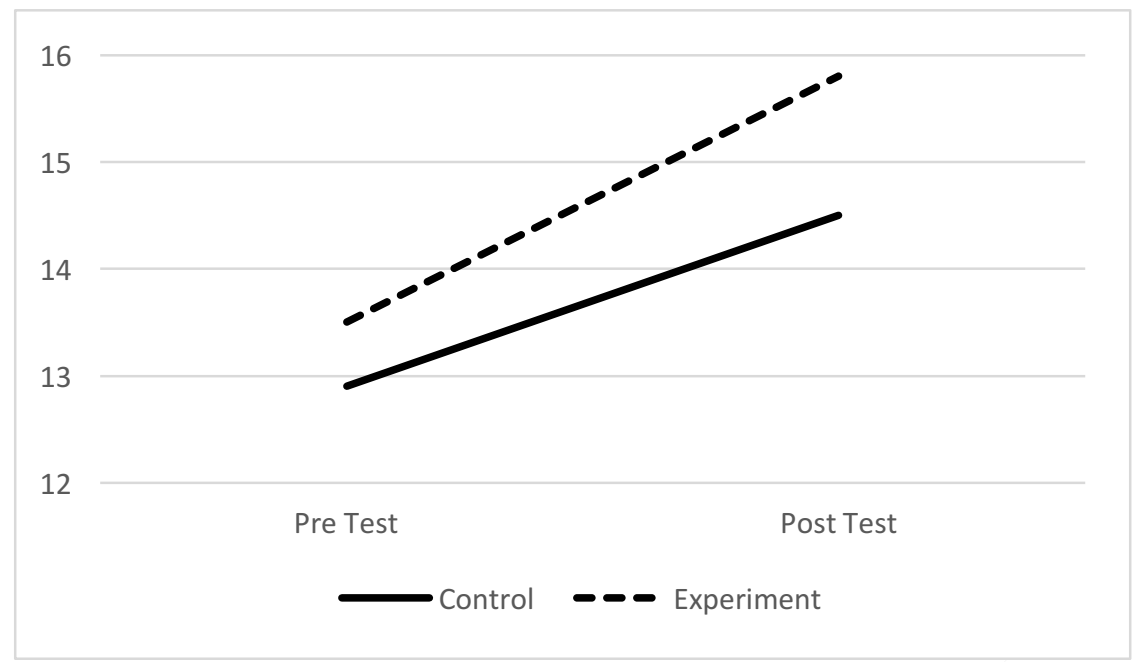

Figure 1. Difference of pretest and posttest mean scores

Figure 1 shows that there is an increase in the result of post-test and pre-test in both control and experiment classes. However, experiment class shows higher gain. Therefore, statistic test was conducted to find out whether or not the pretest-posttest gain of experiment class is different significantly from that of control class.

Variance test is preceded with normality and homogeneity prerequisite test. Normality test is intended to find out whether or not data of experiment and control classes is as same as the normal curve. The normality test selected is Shapiro Wilk test because the size of sample tested is less than 50. The result of normality test is presented in Table 2 .

Table 2. Shapiro Wilk Normality Test

\begin{tabular}{llllll}
\hline Class & Test & Type of Test & Result & Decision & Conclusion \\
\hline Experiment & Normality & Shapiro-Wilk & Sig $=0.097$ & H0 is supported & Normal \\
Control & Normality & Shapiro-Wilk & Sig $=0.065$ & H0is supported & Normal \\
\hline
\end{tabular}

The result of normality test obtains the significance of 0.097 (Sig. $>0.05$ ) in experiment class. Thus, $\mathrm{H} 0$ states that there is no significant difference between data distribution and the standard normal curve accepted. It means that the data of experiment class is distributed normally. Similarly, the data in control class obtains significance of 0.065 (Sig. > 0.05) so that data of control class is distributed normally.

Homogeneity prerequisite test aims to analyze the difference of data variance between control and experiment classes. If the variance of control and experiment classes is homogeneous, the two classes is equal to be compared. The test used is Levene test as presented in Table 3.

Table 3. Homogeneity Test

\begin{tabular}{llllll}
\hline Class & Test & $\begin{array}{l}\text { Type } \\
\text { of test }\end{array}$ & Result & Decision & Conclusion \\
\hline $\begin{array}{l}\text { Experiment } \\
\text { Control }\end{array}$ & Homogeneity & Levene & $\begin{array}{l}\text { Sig } \\
\text { Ho }\end{array}$ & H0 & Homogeneous \\
& & & 0.564 & $\begin{array}{l}\text { is } \\
\text { supported }\end{array}$ & \\
\hline
\end{tabular}


The result of Levene's homogeneity test obtains significance of 0.0564 (Sig. > 0.05); thus $\mathrm{H} 0$ stating that there is no difference of variance between control and experiment classes is supported. The result of prerequisite test on normal and homogeneous data of control and experiment classes becomes the foundation of independent sample T-test. Null hypothesis (H0) proposed is that there is no significant difference of cognitive learning outcome between students in control and those in experiment classes. The result of independent sample $\mathrm{T}$-test is presented in Table 4.

Table 4. The result of independent sample-test

\begin{tabular}{lllll}
\hline Class & Test & Result & Decision & Conclusion \\
\hline $\begin{array}{l}\text { Control } \\
\text { and Experiment }\end{array}$ & independent & Sig. $=0.038$ & $\begin{array}{l}\text { H0 is not } \\
\text { supported }\end{array}$ & $\begin{array}{l}\text { There is significant } \\
\text { difference }\end{array}$ \\
\hline
\end{tabular}

Table 4 shows that the significance value of independent sample T-test is 0.038 ( $\mathrm{Sig}$. $<0.05$ ), so that $\mathrm{HO}$ is not supported, indicating that there no significant difference of cognitive learning outcome between control and experiment classes. The conclusion that can be drawn from independent sample t-test is that the use of interactive multimedia in excretion system improves the cognitive learning outcome of students in Semendawai Suku III Senior High School.

Cognitive dimension is divided into 6 aspects: recalling, understanding, applying, analyzing, evaluation, and creating (Krathwohl, 2002). Cognitive learning outcome is one of human ability varieties. Cognitive ability relates to students' ability of acquiring knowledge and human's attempt of identifying itself and its environment. Cognitive learning outcome is plastic in nature, so that it can be improved through learning activity. It is in line with Suparno's stating that learning is students' process of constructing their own knowledge actively (Sofyan, 2019; Supono, 2007).

Interactive multimedia improves students' curiosity with the material. Therefore, students are motivated to learn more vigorously. It is in line with Haryoko mentioning that learning multimedia in the learning process can generate new wish and interest, learning motivation and activity stimulation, and affects the students psychologically (Han \& Niu, 2019; Sarac, 2017; Haryoko, 2009). Compared with other learning media, multimedia has several features other media do not have: 1) interactive multimedia can display material sequence according to the students' need; 2) multimedia can display feedback to students in the form of notification, review, and item; 3) Multimedia enables the teachers to monitor the students' learning development so that the learning control can be conducted in more structured manner and more systematically (Priyanto, 2009; Suprihatin, 2015). 1) Multimedia can present a variety of elements other media do not have, including text, image, audio, video, and animation; 2) the use of multi-element in multimedia gives varying stimulation to students' brain; 3) multimedia has high flexibility and portability so that learning with multimedia is not limited by space and time; 4) it presents a new way of interacting between teacher and students, for example, through discussion and feedback; 5) it improves students' motivation to learn the material (Miarso, 2005; Nurjanah et al., 2014). Many advantages elaborated practically enable the students to learn joyfully and improve the interaction between students and lesson material. Therefore, the students' learning outcome improves (Goodnough, K \& Cashion, M, 2003). 


\section{Conclusions}

Considering the result and discussion elaborated, it can be concluded that there is a significant difference of cognitive learning outcome between student using interactive multimedia and those using conventional learning media in excretion system, as indicated with statistic independent sample t-test at significance level of 0.038 (Sig. $<0.05$ ). The mean score of cognitive learning outcome for the students in experiment class is higher than that in control class.

In this study, the operational field testing of interactive multimedia based on mobile learning is still limited to one school, especially in the XI class which consists of 64 students who are used as research samples and are still limited to one learning theme taught by the teacher in one particular subject.

Along with the development of information and communication technology which has influenced various fields of life, especially in the field of education. Information technology is able to provide various facilities both through hardware and software that can function as a learning medium in the form of interactive multimedia. Graphics processing software, such as Corel Draw, sound processing software, such as Adobe Audition, animation processing software, such as Macromedia Flash and Adobe Flash, and software for Android-based application makers such as Smart Apps Creator and Adobe Flash (Action Script 3). So, the availability of various kinds of supporting tools to develop a multimedia learning product as a medium to support the learning process needs to be developed even more. Interactive multimedia is one of the technologies that can provide many benefits in achieving learning goals, such as learning achievement, learning motivation and character building of students, it will be optimal if during the learning process it is assisted by interactive multimedia.

\section{References}

Abdillah, R., Sunardi, S., \& Ardianto, D. T. (2018). Pengembangan Aplikasi Multimedia Pembelajaran CD Tutorial Pada Mata Kuliah Berbasis Praktik. Teknodika, 16(1), 53. https://doi.org/10.20961/teknodika.v16i1.34755

Behera, Santosh Kumar. (2013). M-Learning: A New Learning Paradigm. International Journal on New Trends in Education and Their Implications April 2013 Volume: 4 Issue: 2.

Dadang Marsa, Sardiarinto. (2013). Pengenalan Bahasa Inggris Untuk Anak Melalui Aplikasi Edukasi Berbasis Android. ISSN:2089-9815. Yogyakarta: SENTIKA Maret 2013:156-162.

Edwards, A., \& Wilson, J. R. (2017). Communication Strategies. In Implementing Virtual Teams (pp. 77-80). Routledge. https://doi.org/10.4324/9781315587998-11

Goodnough, K \& Cashion, M. 2003. Ostering Inquiry Through Problem Based Learning. The Science Teacher, 70 (9): 21-25.

Guan, N., Song, J., \& Li, D. (2018). On the Advantages of Computer Multimedia-aided English Teaching. Procedia Computer Science, 131, 727-732. https://doi.org/10.1016/j.procs.2018.04.317

Guzman, A. L., \& Lewis, S. C. (2020). Artificial intelligence and communication: A HumanMachine Communication research agenda. New Media \& Society, 22(1), 70-86. https://doi.org/10.1177/1461444819858691

Han, M., \& Niu, S. (2019). Effect of Computer Multimedia Assisted Word Annotation on Incidental Vocabulary Acquisition of English Reading. International Journal of Emerging Technologies in Learning (IJET), 14(13), 21. https://doi.org/10.3991/ijet.v14i13.10705 
Haryoko, S. 2009. Efektivitas Pemanfaatan Media Audi-Visual Sebagai Alternatif Optimalisasi Model Pembelajaran. Jurnal Edukasi, 1(5):1-10.

Krathwohl, D. R. (2002). A Revision of Bloom's Taxonomy: An Overview. Theory Into Practice, 41(4), 212-218. https://doi.org/10.1207/s15430421tip4104_2

Komalasari, K., \& Rahmat. (2019). Living values based interactive multimedia in Civic Education learning. International Journal of Instruction, 12(1), 113-126. https://doi.org/10.29333/iji.2019.1218a

Kumar, J. A., Muniandy, B., \& Wan Yahaya, W. A. J. (2019). Exploring the effects of emotional design and emotional intelligence in multimedia-based learning: an engineering educational perspective. New Review of Hypermedia and Multimedia, 25(1-2), 57-86. https://doi.org/10.1080/13614568.2019.1596169

Lau, R. W. H., Yen, N. Y., Li, F., \& Wah, B. (2014). Recent development in multimedia e-learning technologies. World Wide Web, 17(2), 189-198. https://doi.org/10.1007/s11280-013-0206-8

Leutner, D. (2014). Motivation and emotion as mediators in multimedia learning. Learning and Instruction, 29, 174-175. https://doi.org/10.1016/j.learninstruc.2013.05.004

Maharani, Y. S., Suryani, N., \& Ardianto, D. T. (2018). Pengembangan Multimedia Pembelajaran Interaktif Pada Mata Pelajaran Pengolahan Citra Digital di Sekolah Menengah Kejuruan Negeri 8 Semarang. Teknodika, 16(1), 73. https://doi.org/10.20961/teknodika.v16i1.34757

Mayer, R.E. \& Moreno, R.,. (1998). A split-attention effect in multimedia learning:evidence for Dual proccessing systems in working memory. Journal ofEducational Psychology, 90: 312-320.

Miarso, Yusufhadi. (2005). Menyemai Benih Teknologi Pendidikan. Jakarta: Kencana.

Moeliono, Anton M. (2003). Kamus Besar Bahasa Indonesia. Jakarta : Depdikbud.

Munir. 2012. Multimedia Konsep \& Aplikasi dalam Pendidikan. Bandung: CV Alfabeta.

Neo, M., \& Neo, T. K. (2010). Students' perceptions in developing a multimedia project within a constructivist learning environment: A Malaysian experience. Turkish Online Journal of Educational Technology, 9(1), 176-184. http://www.tojet.net/articles/v9i1/9120.pdf

Nurjanah, Suryadi, D., Sabanda, J., \& Darhim. (2014). the Enhancement of Junior High School Students Computer-Based Interactive Multimedia Instruction. International Journal of Education, 7(2), 111-119.

Priyanto, D. (2009). Pengembangan Multimedia Pembelajaran Berbasis Komputer. INSANIA, 14(1), 92-110. http://ejournal.iainpurwokerto.ac.id/index.php/insania/article/view/320

Santoso, Sastropoetro. 1982. Pengertian Pelaksanaan. UI Press. Jakarta

Saputri, D. Y., Rukaya, R., \& Indri, M. (2018). Need Assessment of Interactive Multimedia Based on Game in Elementary School: A Challenge into Learning in 21st Century. International Journal of Educational Research Review, 3(3), 1-8. https://doi.org/10.24331/ijere.411329

Sarac, H. (2017). Effect of Multimedia Assisted 7e Learning Model Applications on Academic Achievement and Retention in Students. European Journal of Educational Research, 6(3), 299-311. https://doi.org/10.12973/eu-jer.6.3.299

Schramm, W. 1977. Big Media Litle Media. London : Sage Public-Baverly Hills.

Serin, H. (2018). A Comparison of Teacher-Centered and Student-Centered Approaches in Educational Settings. International Journal of Social Sciences \& Educational Studies, 5(1), 164-167. https://doi.org/10.23918/ijsses.v5i1p164

Sholihah, A. N. N., Septiani, I., Rejekiningsih, T., Triyanto, \& Rusnaini. (2020). Development of interactive multimedia learning courseware to strengthen students' character. European Journal of Educational Research, 9(3), 1267-1279. https://doi.org/10.12973/eu-jer.9.3.1267 
Singh, R. (2016). Learner and Learning in Digital Era: Some Issues and Challenges. International Education \& Research Journal [IERJ], 2(10), 92-94. http://ierj.in/journal/index.php/ierj/article/view/508

Sofyan, F. A. (2019). IMPLEMENTASI HOTS PADA KURIKULUM 2013. INVENTA, 3(1), 1-9. https://doi.org/10.36456/inventa.3.1.a1803

Sugiyati. (2016). Pengaruh Media Pembelajaran Dan Minat Belajar Terhadap Hasil Belajar Matematika. 1(3), 227-241. https://doi.org/10.22236/JPPP

Sugiyono. (2013). Metode Penelitian Kuantitatif, Kualitatif dan R\&D. Bandung: Alfabeta.CV

Suparno, P. (2007). Metodologi Pembelajaran Fisika Konstruktivistik \& Menyenangkan. Yogyakarta: Universitas Sanata Dharma.

Suprihatin, Siti. (2015). "Upaya Guru dalam Meningkatkan Motivasi Belajar Siswa".Jurnal Pendidikan Ekonomi, Vol. 2, No. 1, Hal: 74.

Suyantiningsih, Munawaroh, I., \& Rahmadona, S. (2016). PENGEMBANGAN MULTIMEDIA PEMBELAJARAN BERBASIS SCIENTIFIC APPROACH TERINTEGRASI NILAI KARAKTER. Jurnal Kependidikan, 46(1), 1-13. https://doi.org/10.21831/jk.v46i1.9571

Park, B., Plass, J. L., \& Brünken, R. (2014). Cognitive and affective processes in multimedia learning. Learning and Instruction, 29, 125-127. https://doi.org/10.1016/j.learninstruc.2013.05.005

Wang, J., Mendori, T., \& Hoel, T. (2019). Strategies for Multimedia Learning Object Recommendation in a Language Learning Support System: Verbal Learners Vs. Visual Learners. International Journal of Human-Computer Interaction, 35(4-5), 345-355. https://doi.org/10.1080/10447318.2018.1543085 